\title{
Creativity, the Arts, and the Future of Work
}

\author{
Linda F. Nathan
}

\section{INTRODUCTION}

As long as there have been futurists and science fiction writers, there have been predictions that the future would deliver a world without the drudgery of work and with more leisure time and personal freedom for all. Whether the "age of technology and the machine" (Burton 2015) will ever be realized is unclear. Nevertheless, society faces a central challenge of how to better prepare young people for an uncertain future where progress and opportunity—social, economic, and environmental—cannot be assumed.

Education, on some level, contributes to "the common good, enhances national prosperity and supports stable families, neighborhoods and communities" (Pellegrino and Hilton 2012). However, this statement assumes there to be a linearity between the present and the future. I believe that in order to prepare students for the future that is unfolding now, an educational approach that incorporates creativity and arts-based learning is critical to developing resilient, adaptive citizens that can build the stable families and communities of the future.

\section{F. Nathan $(\varangle)$}

Harvard Graduate School of Education, Cambridge, MA, USA

L. F. Nathan

Center for Artistry and Scholarship, Boston, MA, USA

e-mail: Inathan@artistryandscholarship.org

(C) The Author(s) 2019 
This chapter asks a central question about the role of creativity and arts education: how can this emphasis contribute to a more sustainable society and even the future of work (Hellstrom et al. 2015)? How do artists think about creativity and how might schools do the same? I consider an educational case study of the Boston Arts Academy and describe teaching and learning at this one institution. I explain how an intensive education in the arts prepares students with passion to engage an uncertain future, even if they have fewer advantages than most American students. My concluding remarks emphasize the essential qualities of persistence, passion, and practice for success in life and work.

\section{The Future OF Work}

A growing body of literature by philosophers, economists, social scientists, and technologists foretell futures of work that crowd around two distinct outcomes: a dystopia of extreme polarization or an Eden of creativity and cultural production (Brynjolfsson and McAfee 2016; Thompson 2015; Sundararajan 2015).

The practice of work happening in a single place for a fixed period of time has entirely eroded for many professionals today. The workplace can span states, continents, and time zones. With new technologies and digital collaboration tools, co-workers can meet both synchronously or asynchronously no matter where they are located or there preferred working hours. These realities reflect both a demand for more work flexibility and a broader transformation of how we work. Today's entrepreneurs want to decide how "they should define and tackle specific problems and tasks, and when and where work should be done" (Ake Ouye 2011). Couple this with the pressure for greater sustainability, companies now manage workplace design, commuting patterns, air travel practices, greenhouse gas emissions, and food service as part of their operations portfolio. And this trend seems to be increasing as younger workers demand more flexibility in work schedules and alternative workplaces (Hellstrom et al. 2015).

With these trends in the workplace, what are the implications for the future of work and the skills needed for future workers? Clearly, workplaces need to distribute the settings where work is conducted. The notion of a Central Office must evolve and respond to the diversity of needs and include ways to support collaboration. As the workplace has become more diffuse, the challenge of keeping workers engaged, 
focused, and connected to mission and vision becomes more problematic. With less daily face time, how do people stay connected? If workers are spread out geographically, work practices need to adapt. Even though workplaces and work itself may be changing, social skills such as empathy, cooperation, communication, and flexibility remain in high demand. Employers want a workforce that understands how to persist with tasks and learns to communicate both up and down hierarchies, as well as laterally with colleagues. Finally, every employer wants workers who understand how to problem-solve.

As these developments disrupt the workplace, public education systems have largely not kept pace, or have even been included as part of the conversation. Post-secondary education is nearly unaffordable for large segments of the population in the United States. Yet the mantra "College and Career Readiness" was a rallying cry and effectively federal policy during the Obama Administration. Nevertheless, career readiness was a muted tagline as doubts increase that a college degree will prepare graduates for their future careers, or more fundamentally, that they will be as prosperous as their parents. With respect to the uncertain and ambiguous future of work, coherence and direction is lacking in educational policy.

\section{Looking to the Future Through Creativity}

The Partnership for 21st Century Skills posits that The 4Cs: Communication, Collaboration, Critical Thinking, and Creativity are the central skills and dispositions that all students must master to be successful in our increasingly complex world (Partnership 2010). An education centered in creativity and the arts may hold promise for such a twentyfirst Century approach to teaching and learning.

In their seminal book, Hetland et al. (2013) describe a series of eight studio habits of mind that they observed in various schools and programs with strong visual arts curricula. They identify the habits that artistsand arts teachers-tend to employ as:

1. Develop Craft: Learning tools, materials, and artist's practices.

2. Engage and Persist: Learning to pursue topics of personal interest; develop focus, ways of thinking to persevere.

3. Envision: Picturing, imagining what cannot be observed.

4. Express: Creating works that convey ideas, meaning, or emotions. 
5. Observe: Learning to view visual, audio, and written resources more critically.

6. Reflect: Learning to think and converse about one's work and processes of making.

7. Stretch and Explore: Learning to stretch beyond perceived limitations, explore, and learning from errors or accidents.

8. Understand Art World: Learning about art history and artistic practices and engaging the arts community.

The habits provide insight into the ways arts teachers teach and art students learn, and are not necessarily linear or hierarchical. The first habit, development of craft, involves learning about technique, understanding artistic conventions and the use, practice, and care of materials as well as the organization of studio space. Another habit refers to learning about art worlds beyond the classroom such as art history and artistic communities of practice such as galleries, curators, and critics. The six remaining habits, which are seen in serious and high quality visual arts classes, involve general cognitive and attitudinal dispositions towards learning. These six habits are also used in many daily activities as well as various academic pursuits. Causal research about success in the arts and the relationship to success in academic endeavors is still needed, yet current research suggests that the development of artistic habits of mind supports students' interests in innovation (Winner et al. 2013).

The Hetland et al. research is further supported with studies by Eliot Eisner (2002). These scholars demonstrate how the arts help students develop flexibility, expression, and the ability to shift direction (Hetland et al. 2013, p. 7). There is clear evidence that arts learning is not just an "emotive" discipline but one that requires deep reflection and intellectual rigor. In my own work (Nathan 2009), I describe how we teach the arts not so that students will get better at other subjects such as math (the now debunked "Mozart effect"), rather we teach the arts because they are necessary for enabling their maximum personal development. The arts are a critical part of a young person's education because they are vehicles for instruction about tolerance, diversity, and the importance of human understanding. In my experience, as our students develop these studio habits of mind, they tend to achieve more success in school and in life outside of school - a finding which will be demonstrated with a case study later in this chapter. 
The literature on imagination also supports the importance of creativity and the arts in education. In socio-emotional studies, imagination involves the ability to envision a productive future, and take steps to become the person you want to be in that future (Killingsworth and Gilbert 2010). Young people who are immersed in an education system that values and promotes creative and critical thinking will rise to demand what even they did not think possible. Over my many years, as a faculty, school leader, and teacher, my colleagues and I debated how to define creativity and imagination. In the end, we knew both mattered and we experimented with many different curricular innovations with our students to expand the opportunities for creative and critical thinking through the arts. Yet the question persists: what is creativity and how do artists and designers understand its significance to their work?

\section{What Is Creativity and Why It MatTers}

Architect and author Kyna Leski describes creativity as “...a storm that slowly begins to gather and take form until it overtakes you-if you are willing to let it” (Leski 2015). And later, “...the quality of making, inventing, or producing - rather than imitating-and it's characterized by originality and imagination" (Leski 2015 , p. 29). In this way, Leski depicts creativity as a form of problem solving.

Philosopher and psychologist Mihaly Csikszentmihalyi characterizes creative processes as a state of flow — which he describes as a state of concentration or complete absorption with the activity and situation at hand. Flow is another term for the sense of being in the zone or in the groove. Incidentally, people tend to be most happy in this flow state where they are neither too challenged (a source of anxiety) nor too bored.

Csikszentmihalyi described flow as "being completely involved in an activity for its own sake. The ego falls away. Time flies. Every action, movement, and thought follows inevitably from the previous one, like playing jazz. Your whole being is involved, and you're using your skills to the utmost" (Csikszentmihalyi 1990, 2004). While Csíkszentmihalyi doesn't use the precise word creativity, I believe his definitions echo Leski's description of creativity. He describes how when “a person's mind or body is stretched to its limits in a voluntary effort to accomplish something difficult and worthwhile," wonderful moments and outcomes can occur. 
Playwright and actor Melinda Lopez described how she achieves flow in a keynote for the National Artist Teacher Fellowship in 2015:

I have always made plays. I started writing because I wanted to know what I had to say. It is a process of intense isolation in writing and intense collaboration when in rehearsal. I see it like preparing to run a marathon. I have to do a little bit every day. Then, I will get there. I can't find equilibrium if I don't write.

For Lopez, writing requires large chunks of unstructured time to move fluidly between thinking and writing. She writes that during this time, she won't be available for others, she may not eat regularly, and that she tries to take a walk because the physical activity helps her focus. Indeed, many artists talk about how ideas come to them when they are in the shower, or taking a walk, or even right after waking up. But during this time, she is typically not very good company for her family: "And they understand that. They know this is my profession." She also described the power of giving her writing away; losing control of something she worked so hard to perfect. That is what a playwright does and is common in so many creative pursuits. Someone else will direct her work and act in her play. Her words, therefore, must stand on their own.

Lopez defines creativity in much the same way as the others: "Creativity is a muscle that responds to training and practice and discipline." I would argue that this is precisely the view the should be commonly held in school systems (i.e., the opportunity for creativity must not be a special event, but a common practice-a condition).

Lopez added one more insight: "I believe we can be creative in microscopic particles." The meaning of this statement is not immediately obvious. However, I take it to suggest that creativity is often thought of as trait only some people possess. And that if they do, it is overwhelming, virtually constituting their entire identity. Lopez is proposing the opposite: that all people have access to creativity, even if it is only fleeting.

As a school leader, I have worked to imbue the power of art making as a strength that can be translated into other arenas. Once a student has done one thing well and successfully, we have seen that the student's ability to achieve more is increased. We teach that success begets more success. Our arts-based curriculum enables students to effectively 
communicate with others and understand or empathize with events or social issues of our time. As a result, we see our students continually willing to take on new and more difficult challenges. Artists, perhaps more than others, can embrace mistakes. As Ornette Coleman, the jazz musician said, "When I found out I could make mistakes, that's when I knew I was on to something." Traditionally, schools have eschewed mistakes; students learn only to find the one right answer. But this approach not only limits a student's access to creativity and imagination, it can limit learning.

\section{Creative Arts at Work}

In Boston, Massachusetts, Mayor Martin Walsh has initiated a cityfunded program called Boston AIR (artists in residence) to integrate artists in residence into City departments. The goals are two-fold: first, to support the creation of great art and second, to explore urban challenges in new and innovative ways. The program is based on the assertion that creativity and the arts can help bring new perspectives to solve seemingly intractable urban problems of violence, racism, substance abuse, and blight. Five City departments: Boston Police Department, Neighborhood Development, Parks and Recreation Department, the Office of Women's Advancement, and the Office of Recovery Services will have the opportunity to learn and grow alongside their own artists in residence. In 2016, ten artists were selected and funded from a large pool of applicants. The resulting process of artists and city departments learning together to expand their own civic and social activities has transformative potential. As Mayor Walsh explained, "Boston AIR (Artist in Residence) is just one of the many ways we're working to invigorate Boston's cultural scene and support local artists whose innovation and creativity can benefit the people of Boston."

One selected artists from the first cohort (2015) was violinist Shaw Pong Liu. Her proposal, Time to Listen, experimented with ways that collaborative music-making can create a different kind of time, connection, and space for healing and dialogue about the difficult topics of gun violence, race, and law enforcement practices. She worked with the Boston Police Department as well as two local not-for-profit youth organizations to model innovative approaches to police-to-community dialogue on gun violence and race. 
The notion of embedding artists into various city departments in order to elucidate social issues has precedent. Mierle Laderman Ukeles became the first artist in residence in New York City's Department of Sanitation in the 1970s. The impetus for her performance art work was New York City's sanitation workers who were largely invisible to the rest of the city's population. The City's residents expected clean and uncluttered sidewalks, but had little idea about who was actually doing that work. Ukeles' art focused on sanitation workers and how they lived in order to challenge the negative stereotypes associated with sanitation as a process and the workers who carry out the challenging work. A brochure, advertising her unpaid employment in the department from 1979, states "Public Art with Public Workers in Public Spaces for the Whole Public." In her first year in residence, Ukeles shook hands with each of the 8500 sanitation workers across the five boroughs and thanked them for the work they did keeping New York City clean. She also interviewed many and recorded her conversations in order to create an exhibition called "Touch Sanitation" (Kastner 2002). Ukeles could, through art, express some of the frustration felt by sanitation workers who believed that the public perceived them to be part of the garbage. Her work began to change public perceptions by revealing the nexus of waste, culture, visibility, and power. "After the revolution, who's going to pick up the garbage on Monday morning?" she asked.

What is new in Boston's AIR program is a commitment to integrate people with diverse perspectives and skill sets into one City department and to provide a $\$ 22,500$ stipend to each artist. By allocating funds for this work, the city acknowledges the important role that creative endeavors can have in working to solve society's most difficult challenges. The prospect of a musician, visual artist, and quilt maker as well as a video artist charged with helping to solve problems, both large, and small, can appear unorthodox. Yet supporters of these programs believe that this way of working holds the secret to a sustainable future. As Ukeles said, "Public art can create permeable membranes between the inside and outside of systems, spaces, and even the souls of citizens. Public artists need more breathing space to experiment and do R\&D. They need to be brought in at the very inception of projects, so they can do their first work as a certain kind of thinker" (Kastner 2002). By embedding the Boston artists early on in departmental projects, the results may be as stunning and surprising as Ukeles' enduring work. 


\section{Creativity and the Future of Work}

David and Tom Kelley, the founders of IDEO, an international design and innovation firm, insist that creativity is not limited to artists and designers. As with Lopez and others, they stress that creativity is like a muscle that must be continually exercised or it will atrophy.

The Kelleys describe phases of creativity they have observed in the workplace; the first phase being most important: one must choose creativity (Kelley and Kelley 2013). This involves tolerating ambiguity when you are not certain you are on the right path. A creative orientation means one will take risks and accept failure as part of an innovation process. One must confront obstacles when they arise and redefine problems in new ways in order to seek innovative solutions. They suggest ideas such as "think like a traveler" which may allow you to adopt a mindset of seeing things as novel, or from a child's eye. "Think like a traveler" acknowledges the importance of learning from different cultures or organizations and from people quite different from those you are accustomed to. They also stress the importance of "engaging in relaxed attention."

Daydreaming, or being at relaxed attention, runs antithetical to much of the current educational literature about "grit" (Duckworth 2016; Perkins-Gough 2013) and much of the re-emerging "no-excuses" movement in education reform. As educational psychologist Mary Helen Immordino-Yang and her colleagues wrote, "rest is not idleness" (Immordino-Yang et al. 2012). We must help young people (and educators) realize that often our brains can make the largest cognitive leaps when we are not obsessed with solving a challenge, but we are resting or allowing our thoughts to meander. Since we engage in imaginative daydreaming for many of our waking hours, it's important to understand the connection between imagination and creativity (Killingsworth and Gilbert 2010). That is when we can generate new ideas and solutions. Creativity does not exist without imagination (Davis et al. 2004). Cognition is associated with attempts to empathize: how do we imagine the perspective of another. If we agree that a critical twenty-first Century skill or global competence involves the ability to generate questions and seek answers about the world, take others' perspectives, communicate with different people, and address societal issues, then we must develop deeper understanding of the connections between imagination and creativity (Boix Mansilla and Jackson 2013). 
The Kelleys helped to introduce an approach called Design Thinking, which is both a practical and creative approach to problem solving and product development. Design Thinking emphasizes a series of iterative steps beginning with empathy or seeing the experience through the end-user's perspective. The next phases have to do with generating a proposal and refining a product: define, ideate, refine, test, and prototype. Unlike other problem solving approaches, Design Thinking, through its emphasis on empathy as well as divergent thinking, strives to generate more future-oriented, human-centered solutions. Although the future of work may demand creativity, it is the most under-developed and ignored skill in most of our schools.

Within respect to schools, an understanding and application of Design Thinking could greatly enhance our approaches to teaching and learning. Without empathy, students cannot deeply understand a new context or issue or begin to think through how to make sense of new information. If we want schooling to prepare young people for the ambiguities and uncertainties of the future of work, putting arts learning and creativity at the center of education may be just the approach we need. Arts-based learning enables students to develop the very skills that futurists say we need most: persistence (learning how to practice and commit to something through many revisions), collaboration (working together on a play, a music ensemble, curating a gallery show, choreographing and performing a dance), communication (making sure everyone in the ensemble or cast knows what's going on, at what time, and how the action or event will flow), critique (being able to distill what one likes/doesn't like in a piece of work, helping others grow from criticism, connecting the work to those that came before-in other words, on whose shoulders do you stand?), and resilience (the capacity to recover quickly from difficulties or even toughness).

\section{Learning with the Arts: A Case Study of Boston Arts ACADEMY}

Boston Arts Academy (BAA), a school that I founded in 1998, is Boston's only visual and performing arts public high school. There are 440 students in grades nine through twelve (secondary school). Over $65 \%$ of students receive free and reduced lunch, which is the federal government's indicator for families living at or below the poverty level (about $\$ 44,000$ for a family of four). The school is about $40 \%$ African 
American, 44\% Latino or Hispanic, and 13\% Caucasian and about 3\% Asian American. About 16\% of the students are considered in need of special education services and have an Individualized Education Plan. Many are also considered English Language Learners (they speak a language other than English at home). While these demographics reflect the city of Boston, most Boston Public high schools are often much poorer and with fewer Caucasian students than BAA. One of the hallmarks of BAA is its socio-economic and racial diversity. Another remarkable characteristic is its high college acceptance rate at $94 \%$. In a recent study, $63 \%$ of our graduates had either finished college within six years or the more recent were still pursuing higher education. The national rate for college graduation in the United States hovers around 56\% and is much lower for students of color or from low socio-economic backgrounds.

Auditions are required for enrollment at BAA and no academic tests are considered for admissions decisions. In other words, students are accepted based on their passion for the arts. Since they will spend a minimum of two hours per day learning a specific arts discipline (music, dance, theatre, or visual), it is critical that they want to be there. While not all schools can select students based on passion, I have long argued that we would better serve our young people entering secondary school if we required that they begin to articulate what they want to learn and why (Nathan 2009, 2017; Robinson 2015). This is often called career and technical education, but it need not be that specific. If students had to think and write and reflect upon their dispositions towards learning, and their passions, before entering secondary school, I believe much of their first year would be an exploration into possibilities rather than feeling like a $\operatorname{cog}$ in a big wheel over which they have no control. Similarly, if all students were given multiple opportunities to ask and examine what they wanted to learn, attitudes towards schooling might improve, especially for students who feel disconnected from and alienated by school.

BAA is part of a movement of schools called Coalition of Essential Schools (www.essentialschools.org) that developed in the late 1980s based on the work of Theodore Sizer (Sizer 1984, 1992, 1996). More recently these ideas have been renamed "deeper learning" (Martinez and McGrath 2014). The premise and research to support these approaches suggest that when students are given opportunities to engage in projects over time, to take risks, to fail, and recover, significant improvements occur in critical thinking and communication skills. These skills have strong correlation to cognition and thus, achievement in school. 
Increasingly, research points to schools that teach students to adopt a "growth mindset," will also lead to stronger academic success. This mindset is a belief that intelligence is not fixed but something that can grow and change over time (Dweck 2006). I will discuss this more below.

BAA specifically teaches a set of four dispositions towards learning. These habits of mind we call the Habits of the Graduate. They are: Refine, Invent, Connect, and Own. The terms, and the way they are taught and used, mirror much of the deeper learning literature and also reflect theories underlying a growth mindset. The habits are not taught or used in a particular order, yet the power of these dispositions allows students to become more independent, self-aware, and confident learners. These habits coordinate easily with the dispositions that futurists say we most need for work success and in an uncertain future. In order to Refine a piece of academic or artistic work, you must possess both resiliency and persistence. Students ask: "have I conveyed my message? What are my strengths and weaknesses?" Although sometimes the process of Invent happens alone, it is often an outgrowth of collaboration. Through working deeply with others, new ideas can emerge. Students ask: "what makes this work inventive? Do I take risks and push myself?" Connect and $O w n$ link to the ability to communicate and to both give critiques and be critiqued. To better understand Connect students ask: "who is the audience and how does the work connect? What is the context?" And for Own: "am I proud of the work I am doing? What do I need to be successful?" These habits align easily with the same habits required of the twenty-first Century workforce.

Certainly, more schools today emphasize collaboration and group projects, but the very "grammar of schooling" (Tyack and Cuban 1995), or the way the day and classes are structured has not changed much in 100 years. For the most part, students are not exposed to the kind of thinking and ways of working that they will use just four or eight years later. Fortunately, this is not the case at BAA. While emphasizing the attainment of academic skills, students must complete lengthy and longterm academic and creative projects.

The most remarkable part of a BAA education is the Senior Grant Project, which students begin in their junior year (11th grade). They must define a project, which benefits a community, and then bring their artistic and academic skills to bear to constructively address that problem with a project design. They must first show empathy and understanding. Some examples include: how to help young cancer survivors through 
music; working with homeless teens through developing short plays that reflect their challenges; developing engaging marketing materials for after-school programs that would raise awareness and hopefully more funds. Some students have worked with community policing to develop programs that better engage young people in resisting gang involvement. The list of projects is long, and the requirements are specific and stringent. Students must complete a letter of intent that demonstrates that they understand the challenges involved with addressing the particular problem they want to influence. They must develop a feasible budget, and they must get buy-in from the organization they will work with. Finally, they must demonstrate how both their academic and artistic skills are put to use in working on their challenge. I believe most adults would struggle with projects of this nature.

The requirements of the project position students to think and act like entrepreneurs, but also as artists and collaborators. They need to deeply understand the organization for which they plan to provide services. They begin to learn about philanthropy through practicing grant writing. In creating a budget, they also learn about asking for in-kind resources. Most importantly, students learn how to convince others of value they can provide. And, of course, given the fact that the project evolves over a couple of semesters, students practice sustaining interest and attention. These are all skills that are essential for the future.

At the end of the project, community partners, alongside teachers, are invited to judge both the written work and the quality of the presentations. This creates a level of engagement and authenticity rarely available with papers or tests. The opportunity to have one's work exhibited in this public manner, often in front of people who are decision makers in the community, raises the stakes to demonstrate a high level of mastery. In addition, students work to develop persuasive and creative presentation skills-all skills that are critical to an entrepreneurial approach to work. All students must receive a passing score on their grant project to graduate. About $25 \%$ of students receive actual funding to complete their project.

\section{Raul's Senior Grant Project}

Raul was a percussionist at BAA who proposed teaching drumming to homeless men for his Senior Grant Project. Raul wrote, "There are many innocent people who are left on the streets with no money and no 
chance of work. I have chosen to work with this community of people because I have many ties to people in this situation...." He went on to describe how, after his sessions teaching drumming at a local homeless shelter, he would perform a street drumming concert at a public park with his adult students so they could collect money.

During his final review with outside judges, Raul was asked if he felt that drumming could help alleviate homelessness. His answer was thoughtful. "I'm not trying to get rid of homelessness. That has to do with poverty and lots of other things. I want to teach community drumming so that these men do not have to resort to begging for change." He went on:

Drumming comes from the heart, and I believe if you connect to your heart in honest ways, that could help you get off the street. I grew up with drumming and it helped me get here and get to this school. I think I can show other people that drumming can bring you peace and a sense of control. I always feel in control when I'm drumming and then I'm not depressed.

When asked about his connection to the homeless community, Raul looked down at the floor, and spoke softly, "My uncle was homeless and also my first teacher. He gave me something that no one can ever take away. I want to give something back to him, even if he never can know what I'm doing." While the clients from the shelter would keep their own donations, Raul would give the money they raised back to the shelter-which was the same place that had helped Raul's uncle. He died while Raul was working on his project.

Even though Raul personally connected to his project, he had to refine his proposal more than once to get his writing up to the required standard for acceptance. His persistence was evident as he developed his ideas and thought through some of the critique.

For most of Raul's career at BAA, he just managed to pass. He was a good drummer, and grew a lot over the four years. However, academically he always did the bare minimum, until he had to do the writing and research for Senior Grant Project. He wanted that project to reflect his respect and love for his uncle, and he cared about the issue he was trying to address. How often in students' school lives can they use their passions and skills to solve a problem they care about? This level of engagement should exist in more schools. 
If all high school students had the chance to perform or exhibit work that reflected their deep interests and passions, school would be a place that matters deeply. School could be a place that values creativity.

\section{Creativity Is Not Magic}

Teaching creativity, or at least ensuring multiple and varied creative opportunities in the school day, may hold a key to the future of education, schools, and work. We know that creativity is central to twenty-first Century competencies. Creativity shares the stage with flexibility, critical thinking, collaboration, cross-disciplinary thinking, and even the development of courage. These are skills, along with content knowledge, that many have agreed must be incorporated into all classrooms. However, day-to-day practice tends to favor the attainment of content knowledge and push to the background the development of creativity in most classroom settings. Creativity cannot be mastered without content knowledge. In other words, one cannot be creative about nothing. Students (and a twenty-first Century workforce) must learn to incorporate a both/ and approach to learning and working. Creativity must take center stage alongside facts and figures. Although that does not mean developing a test for creativity, education systems must do a better job ensuring that teachers and students have more creative experiences in their PK-12 education. At BAA, creativity is a discipline taught daily, both in arts and academic classes. It is a muscle that is consistently exercised. Students constantly reflect on their own abilities to create. BAA's dance curriculum is a prime example:

As part of the curriculum, dance faculty member, William McLaughlin, teaches an approach he calls "embodied research." McLaughlin described the term as:

An inquiry-based process, involving the physical response to stimuli. Stimuli might be in the form of text, music, visuals or movement. Participants respond to the stimuli through gestures, which then become movement studies or phrases and finally a fully choreographed dance. (Notes from workshop of Coalition of Essential Schools in Portland, ME, November 6, 2015)

McLaughlin has worked with his dance students to develop a piece called "Speak." This dance grew from an exploration of themes that 
cast members, mostly young men of color, faced growing up in urban America. The student dancers spent early rehearsals sharing stories and experiences about difficult or important moments in their lives such as: the death of a relative, being assaulted by a gang member, a tumultuous break-up of a relationship, or becoming homeless. As students recounted these stories, other dancers responded through gestures. These movement phrases became the basis of the longer piece. The production is set to excerpts from speeches by Martin Luther King Jr. and Robert F. Kennedy as well as the music of Daniel Bernard Roumain. The instrumentation, which is both lyrical and haunting, is a counterpoint to the emotional speeches of the two famous leaders. The percussive action on stage is tense, wildly chaotic, and then symmetrical. The dancers' athletic movements are often in sharp juxtaposition with the text of the speeches. The result is a riveting experience that is both familiar and current since the original stories are universal, yet the piece also carries historical memory and inquiry given the biographies of the two authors. The audience is asked to hold dualities of present day and history, which creates a certain discomfort and level of inquiry: has anything changed in our world?

I recount the nature of the dance "Speak" not as a dance critic but to provide an example of the ways in which young people can work to tackle content knowledge through their passions and talents. In speaking with the young participants, whether they were current students or alumni returning to participate in the piece, they revealed how this way of training - as a dancer-had such meaning. A dancer must both own material and connect that material to self and others. The process prepared them for a life of work, creativity, and problem solving. Furthermore, the training in this particular piece, and others like it, allows young people to comment on the realities of today's world and, through movement and suggest how to make changes. The entire cast has committed to dance as a way to keep violence at bay and to bring beauty into the lives of their communities. As young people, they have developed assets that they know are appreciated by others. The experience gives them a special sense of confidence and agency in their worlds. They perform the piece often for others. They talk about their stories of sadness and violence that are reflected in the piece and also through the texts of King and Kennedy. The dancers speak about how learning skills such as dance have opened doors and opportunities for all of them, and also has given them tools of resilience against despair. For these young 
people, dance is a way of both understanding the world and contributing to its improvement. Agency, as an education outcome, especially for these at-risk youths is a significant and lasting achievement given the social and economic challenges they will face as young adults.

One of the student dancers reflected poignantly about his skills and disposition learned through dance at BAA:

I work as a driver for the elderly with the bus service. I know how to listen. I know how to be compassionate. Of course, that's the kind of person I am, too. But it's also what I learned as a dancer. You have to listen to others. You have to understand what the choreographer wants you to feel. It's not just a movement. It's also a feeling. I bring that to my work with the disabled and the elderly. I love what I do. And I'm good at it. Maybe you'd call it empathy.

Another BAA dance student spoke about his ability to confront racism and violence, and how, as a dancer he can contribute to the long and ongoing struggle in America for racial justice:

As an African American male, every time I hear those words that [RFK] says about Martin Luther King being shot, I just freeze inside. This is today. That is why \#blacklivesmatter is so important. We haven't come so far really. I'm at risk just being a black male. That's why I want to keep doing this piece. I want people to understand that racism and violence will destroy us. We have to make changes. I can start.

Another BAA graduate talks about how his education in dance, and more broadly in the arts (he also studied music at BAA), prepared him for both college and for his current job as a civil engineer:

Being an artist means lots of practice and lots of risk-taking. I have to always put myself out there. It has never been easy. That's the same way I approached my major and my job search. Civil engineering, my major, is all about sitting down and working out problems. I knew how to buckle down from being an artist.

This student then goes on to explain his emerging theory of art and success, which clearly anticipates a future of work very different than the one most students are educated for: 
Since art is constantly changing, it makes artists well-adaptable to different situations. As an artist, you never know what can be thrown at you... and in my field and in my job, it's the same thing. You have to believe you can keep learning and doing new things.

In his own words, this graduate is essentially describing a "growth mindset," referenced earlier in this chapter. The student expands this notion and describes how often solutions come from what he called "going off the grid," which he reconnected to dance as well:

Often, we can't solve the problem in dance just by doing the same movements. Sometimes we have to find a different movement or orientation to express what we are trying to do. That's the same in engineering. It's not always linear. Being able to adapt is key!

McLaughlin, the BAA choreographer and teacher, understands the conditions necessary to developing an adaptive, growth mindset to be inherent in dance, and embodied research:

So much of our daily lives just uses one small part of our brain-usually that part that we call the rationale part-but in dance, as in most art, we are accessing something else. Of course, we have to have beautiful technique. But we are accessing emotion and finding ways to bring peoplethe audience-to inquire with us-and not just through thinking, but through emotion. The piece is both deeply emotive and an intellectual journey. We have to do both together.

I believe that connecting to others through emotion and allowing an audience to be swept off its feet holds promise for solving intractable problems - a position that admittedly challenges the past century or more of science-based evolution of social and political systems. It is time for teachers and students to harness and respect the power of movement, art, and creativity to help us all better understand complex issues. Perhaps by going "off the grid," as the student said, these young men will grapple with issues at a deeper level and have more creative solutions. That is the hope that art inspires. Art helps us solve problems both big and small, and in ways that other disciplines fall short. Art, too, gives these young men, who didn't come from communities with abundant resources, opportunities to experience and influence the world in unique ways. I have witnessed how their artistic skills translate into a world 
where work and economic stability is inherently uncertain especially for marginalized populations, and increasingly, for the rest of us.

One could argue that work has become more like pre-school; learning and working together at the forefront of knowledge. And clearly, these young dancers and now graduates embody skills paramount for success in today's world, including sharing and negotiating. According to educator Michael Horn, "Machines are automating a whole bunch of these things so having the softer skills, knowing the human touch and how to complement the technology is critical, and our education system is not set up for that" (Miller 2015). I dislike the paradigm of soft and hard skills because I think it misses the central idea: we all need both skills of analysis and skills of collaboration. But we have strayed too far from this notion, embracing and valuing analytic skills over all else. We have forgotten that without the head-heart-hand connection, as education philosopher John Dewey wrote, we are much more diminished as human beings.

A great deal of debate in the educational literature focuses on the role of so called non-cognitive skills in learning and in success in life. The notion of living a dignified life, or having a sense of subjective wellbeing, is often attributed to how schools, and also community and home life, can teach these softer skills. Researcher and psychologist Carol Dweck has contributed to this discussion of non-cognitive skills through the development of a concept she calls "fixed" and "growth" mindset. Within the construct of a "fixed mindset," individuals believe that intelligence is static. This means that, although one can learn new things, you cannot change how intelligent you are. You are either smart or not smart. People with fixed mindsets do not believe that effort can change intelligence and so they have a very deterministic view of the world. "I'm not a good reader no matter how much I try." Or "Math is always hard for me. I'm no good in math." In contrast, an individual with a "growth mindset" believes that she can always increase her intelligence. As introduced earlier, someone with a growth mindset, sees "effort as the path to mastery," and is willing to learn through criticism and persist in the face of challenges.

It seems to be a simple concept-mindset is not fixed-but the impact of the alternative narrative has been profound. The notion that anyone can have a growth mindset must be a central tenant of education. An education in and through the arts can have strong positive effects on developing a growth mindset as we saw in the description of the dancers' abilities to persevere and imagine alternative possibilities to their lives. 


\section{STEAM: Preparing Students for the Future of Work}

One of the ways BAA pursued a long-term commitment to creativity and collaboration was by developing a maker-space. We called it a STEAM Lab. For BAA, the term STEAM emerged from the growing emphasis on STEM fields, but we insisted that Science, Technology, Engineering, and Math, without the Arts, was missing a central organ for survival. In addition, students wanted to explore academic and artistic questions in new ways. Students and faculty questioned how their design skills could evolve with new tools. And how might engineering class expand to include issues students were facing in their lighting or costume design classes? The questions seemed endless.

For example, dancers wanted costumes that would light up on the dance floor. Visual artists wanted to paint with gloves on the walls and have each finger exude a different kind of paint. They also wanted to paint with light emanating from each finger. Their authentic need to solve a technical and artistic problem led them into scientific inquiries that explored new territories, domains, and new uses of technology. They learned about Arduino boards, coding, programming, and a host of other technological innovations that allowed them to solve or explore problems in new and innovative ways. They were equally as interested in the science as they were the art.

In science class, curriculum focused on the Human Microbiome Project has included artistic as well as scientific explorations. The project is called Expansive Meanings and Makings in ArtScience, and is funded by the National Science Foundation. A collaborative group of Chèche Konnen Center learning scientists, from TERC, an educational research organization, in Cambridge, BAA faculty, BAA students and alumni, local independent artists, and the Broad Institute at M.I.T., scientists are exploring the potential of an ArtScience repertoire-transdisciplinary practices of cultivating attention, making, and critiquing together with a final, exhibition, performance, and communication-to support high school students in creatively responding to cutting edge phenomena. In this project, students investigate the emerging science of the Human Microbiome through both artistic and scientific models. For instance, to explore their skin microbiome, students are culturing bacteria from their palms, and then building sculptural narratives about the skin microbiome. They explore their emerging understanding of skin microbiome through movement, music, theatre/filmmaking, and painting. 
Throughout the inquiry, by working with science and art faculty, artists, and research scientists, students are learning to integrate artistic and scientific materials, concerns, and processes to create ArtScience stories relating to aspects of the human microbiome they find intriguing, puzzling, significant, or even troubling.

For example, one student, a visual artist, who struggled academically, socially, and emotionally in class, truly excelled in her human microbiome project. She was completely captivated by the idea that she could create an artistic drawing of a scientific phenomenon that she deeply understood. In her project, she used stage makeup to create a representation of how her microbiome looked to her. "When you look at bacteria in the microscope many people are disgusted, but I saw beautiful designs and intersecting parts with potential for many colors." When asked what she wanted people to take away from her art, she said, "I want people to understand the drastic difference between what people think and what it actually is." She felt that she had previously learned science as discrete facts for a test with no real connection to her love of aesthetics or beauty. In this instance, for her, the study of science was both an academic exercise to understand scientific principles and an artistic challenge to present a visual representation that communicated both beauty and her depth of scientific knowledge. The ability to link and explore two disciplines was both gratifying and important to her as a learner. Her final presentation demonstrated just how much she learned both about herself, art, and science.

Dr. Nettrice Gaskins, BAA's STEAM director, offers three recommendations (Gaskins 2016) when thinking about implementing a STEAM program in schools. The parallels between her suggestions and the workplace strike me as both obvious and important. One suggestion is "teach culturally relevant narratives to inspire students from underrepresented minority groups to learn and master tools in innovative ways." Specifically, Gaskins explains that she helps students "produce inventions by merging aesthetic and technical production methods through redeployment, re-creation, and re-conception." One example is how students learn that DJ Grandmaster Flash created a "cross-fader device to mix different audio sources." Since people who do not look like BAA students dominate so much of the field of engineering and design, we must develop materials and examples that reflect their racial, ethnic, linguistic, and cultural backgrounds. Gaskins also emphasizes the importance of providing "choice, autonomy and time for collaboration." These are 
the very skills developed by the dancers in "SPEAK," and they are the skills employers insist they most need and want. When students are given time to collaborate with peers, what emerges is more powerful and farreaching than working alone. In a recent survey of BAA students about their STEAM lab activities, Gaskins reports that "70\% report increased attention, defined as curiosity and interest and 68\% report an increase sense of relevance [which they] defined as linking learner needs, interests and motives." Finally, and perhaps most importantly, "67\% felt increased levels of confidence defined as developing positive expectations for success." Experimentation, risk taking, making mistakes, learning how to explore unfamiliar equipment, or problems are all key components to successful artistry and work.

\section{Has Education Kept Up with Future of Work Trends?}

Teachers, principals, and education policy makers have always grappled with the tensions inherent in questions about the purpose of schooling and education (Dworkin 1959; Sizer 1984, 1992, 1996; Bowles and Gintis 2002; Tyack and Cuban 1995). Is education meant to develop a life of the mind and help young people enter college? Or is it to develop the skills needed for an ever-changing workforce and the economy? Depending on your perspective or role in society, you might have a very different answer. Many argue that by attaining a high level of education, people will live a life of dignity with a sense of purpose, commitment, and excitement about being a member of a community within a larger society. For others, the sole purpose of PK-12 education is either to attend college or attain a worthwhile career. Many would argue that our public school system is for all of these purposes.

In the United States, the current discourse in education reform circles is narrowly focused on the adoption of Common Core national standards. Although national standards have been popular in many other countries, the history of decentralized schooling in the U.S. elicits a fear that Common Core standards may result in more standardized testing. With increasing frequency, a score on a multiple-choice test determines decisions about a student's future and many U.S. students are now tested for up to three weeks per school year. The anti-testing movement has criticized the federal role in mandating tests. However, a Common Core national approach to what students should know and be able to learn has garnered more support. Many argue for common agreement on the 
skills that all students should attain, but not a common set of national standards that adhere to the new mantra of "college and career readiness." Without a significant infusion of career and technical courses and schools, our new federal policies are not likely to bring more equity and access to our most vulnerable students.

In U.S. schools, in this era of high-stakes testing, few schools, whether charter or public, have shown innovative examples of new directions, particularly for urban students. BAA, however, continues to forge advances in teaching and learning with its commitment to high quality arts education and creativity. Perhaps, more remarkable than its high college graduation rate is the number of alumni with their own small performing arts companies. Hardly a month goes by in which I don't notice an announcement in the local paper or on Facebook for a theatre or dance performance involving BAA graduates. The same is true with music and visual arts events: alumni work pops up all over the region. Of course, some of the alumni are now world famous. Kirven Boyd just retired as a principal dancer with Alvin Ailey. Diane Guerrero won the SAG award for best Latina actress and just published her memoir (Guerrero 2016). Most of the graduates are making work in their communities and are finding their ways as artists and scholars. As one graduate recently told me, in reference to her own emerging company, "You taught us to both value and tell our stories. And that's what I've been doing every day."

Another graduate, describing her years at BAA said:

I have lived in a community in which everyone breathed the same air. This air was called art. This school has demonstrated to me the importance of being not only artistically distinguished but also intellectually proficient.... I learned that knowledge is a powerful weapon that could be used to help and change humanity, but that it must be analyzed and owned first. This school developed artists and scholars that now have the power to stand as individuals and support their own perspectives and beliefs. We learned the vitality of appreciating and studying the evolution of man along with the evolution of art through time and history. (BAA Graduation Speech 2012)

Her BAA education helped her to,

....raise and answer questions such as 'How do I use my art to educate society and to effect change in humanity?' or 'How can I use my craft to 
eliminate issues such as ignorance hunger, poverty?' I realized that those are questions that can take an entire life to answer. Art is the most effective and humane weapon to fight injustice and corruption. Art is the true expression of the human being. Art is the key that unlocks the world of the artist, and the artist's response unlocks a world that mirrors society.

In an increasingly complex and uncertain world, BAA graduates have learned to walk in one another's shoes, to sing in a new language, to explore movement that might be totally foreign from their own culture and perspective. They can appreciate the dissonance that comes from discovering differences without fear or disdain. Our alumni can express important life connections through drawing, painting, sculpting and building, and prevent those differences from becoming impediments to change.

\section{CONCLUSION}

Eliot Eisner, American philosopher and professor, made popular the "Ten Lessons the Arts Teach Us" (Eisner 2002). I invite educators and policy makers to study all ten lessons in efforts to create schools that our young people deserve. For now, I highlight three key lessons to embrace in providing our young people with opportunities for a successful future. The arts teach children the following:

1. To make good judgments about qualitative relationships. Unlike much of the curriculum where correct answers and rules prevail, in the arts, judgment-not rules-prevails.

2. The problems can have more than one solution and that questions can have more than one answer.

3. In complex forms of problem solving, purposes are seldom fixed, but change with circumstance and opportunity. Learning in the arts requires the ability and a willingness to surrender to the unanticipated possibilities of the work as it unfolds (Eisner 2002). (Adapted from the National Arts Education Association at www. naea-reston.org.)

Young people need to be able to collaborate and communicate well, and often across differences of language, culture, economic means, gender, and race. An education that stresses creativity and entrepreneurship can 
positively impact a young person's ability to attain meaningful work. An increasing number of jobs require social skills like patience, persistence, and the ability to practice and pay attention in a changing environment. In many urban communities, especially those ravaged by high unemployment and violence, students are missing positive examples of work and beauty. An education in the arts can provide profound examples of beauty and give students the opportunity to write a new script for their lives-literally and figuratively. Our students often come from environments where poverty and lack of access to opportunities are the norm. Their arts education offers a way to enter the world more energetically, flexibly, and confidently. Whether a focus on the arts or any other form of learning, as we think about sustainability in education, may we invest more closely and carefully in the role creativity can and should play.

\section{REFERENCES}

Ake Ouye, J. (2011). Five Trends that are Dramatically Changing Work and Workplace, Knoll Workplace Research. Retrieved from https://www.knoll. com/media/18/144/WP_FiveTrends.pdf.

Boix Mansilla, V., \& Jackson, A. (2013). Educating for Global Competence: Learning Redefined for an Interconnected World. In Heidi Jacobs (Ed.), Mastering Global Literacy, Contemporary Perspectives. New York, NY: Solution Tree.

Bowles, S., \& Gintis, H. (2002). Schooling in Capitalist America Revisited. Sociology of Education, 75(1), 1-18. Retrieved from http://www.jstor.org/ stable/3090251.

Brynjolfsson, E., \& McAfee, A. (2016). Race Against the Machine. Lexington, MA: Digital Frontier Press.

Burton, R. (2015, September 21). How I Learned to Stop Worrying and Love A.I. The New York Times. Retrieved from http://opinionator.blogs.nytimes. com/2015/09/21/how-i-learned-to-stop-worrying-and-love-a-i/?_r=0.

Csikszentmihalyi, M. (1990). Flow: The Psychology of Optimal Experience. New York, NY: Harper and Row.

Csikszentmihalyi, M. (2004). Flow, the Secret to Happiness [Video file]. Retrieved from www.ted.com/talks/mihaly_csikszentmihalyi_on_flow?language=en.

Davis, M. H., Soderlund, T., Cole, J., Gadol, E., Kute, M., Myers, M., et al. (2004). Cognitions Associated with Attempts to Empathize: How Do We Imagine the Perspective of Another? Personality and Social Psychology Bulletin, 30(12), 1625-1635. https://doi.org/10.1177/01461672042671183.

Duckworth, A. (2016, March 27). Don't Grade Schools on Grit. The New York Times. http://www.nytimes.com/2016/03/27/opinion/sunday/dont- 
grade-schools-on-grit.html?rref=collection\%2Ftimestopic\%2FEducation\&action $=$ click \&contentCollection $=$ opinion $\&$ region $=$ stream $\&$ module $=$ stream unit\&version $=$ latest\&contentPlacement $=9 \&$ pgtype $=$ collection\&_r $=0$.

Dweck, C. (2006). Mindset: The New Psychology of Success. New York: Random House.

Dworkin, M. S. (1959). Dewey on Education, Selected, with an Introduction and Notes. New York, NY: Bureau of Publications, Teachers College, Columbia University.

Eisner, E. (2002). The Arts and the Creation of Mind (pp. 70-92). New Haven, CT: Yale University Press.

Gaskins, N. (2016, April 4). The New Face of STEAM [Blog post]. Retrieved from http://www.edutopia.org/blog/the-new-face-of-steam-nettrice-gaskins.

Guerrero, D. (2016). In the Country We Love: My Family Divided. New York, NY: Henry Holt.

Hellstrom, E., Hamalainen, T., Lahti, V. M., Cook, J., \& Jousilanti, J. (2015). Towards a Sustainable Well-Being Society (Working Paper 1.4.2015). Helsinki, Finland: Sitra.

Hetland, L., Winner, E., Veenema, S., \& Sheridan, K. M. (2013). Studio Thinking 2: The Real Benefits of Visual Arts Education. New York, NY: Teachers College Press.

Immordino-Yang, M. H., Christodoulou, J. A., \& Singh, V. (2012). Rest Is Not Idleness: Implications of the Brain's Default Mode for Human Development and Education. Perspectives on Psychological Science, 7(4): 352-364. Retrieved from http://pps.sagepub.com/content/7/4/352.

Kastner, J. (2002, May 19). The Department of Sanitation's Artist in Residence. The New York Times. http://www.nytimes.com/2002/05/19/ arts/art-architecture-the-department-of-sanitation-s-artist-in-residence. html?pagewanted=all.

Kelley, D., \& Kelley, T. (2013). Creative Confidence. New York, NY: Crown Business.

Killingsworth, M. A., \& Gilbert, D. T. (2010). A Wandering Mind is an Unhappy Mind. Science, 330(6006), 932.

Leski, K. (2015). The Storm of Creativity (p. 7). Cambridge, MA: The MIT Press.

Martinez, M. R., \& McGrath, D. (2014). Deeper Learning: How Eight Innovative Public Schools Are Transforming Education in the 21st Century. New York, NY: The New Press.

Miller, C. C. (2015, October 16). Why What You Learned in Preschool Is Crucial at Work. http://www.nytimes.com/2015/10/18/upshot/how-the-modernworkplace-has-become-more-like-preschool.html?_r=0.

Nathan, L. F. (2009). The Hardest Questions Aren't on the Test: Lessons from an Innovative Urban School. Boston, MA: Beacon Press. 
Nathan, L. F. (2017). When Grit Isn't Enough: A High School Principal Examines How Poverty and Inequality Thwart the College-for-All Promise. Boston, MA: Beacon Press.

Partnership for 21st Century Skills. Retrieved from: http://www.nea.org/ home/34888.htm https://www.imls.gov/assets/l/AssetManager/ Bishop\%20PreCon\%202.pdf.

Pellegrino, J. W., \& Hilton, M. L. (Eds.). (2012). Education for Life and Work: Developing Transferable Knowledge and Skills in the 21st Century, National Research Council, of the National Academies. Washington, DC: The National Academies Press.

Perkins-Gough, D. (2013, September). The Significance of Grit: A Conversation With Angela Lee Duckworth. Educational Leadership, 71(1): 14-20. Retrieved from http://www.ascd.org/publications/educational-leadership/septl3/vol71/ num01/The-Significance-of-Grit@-A-Conversation-with-Angela-LeeDuckworth.aspx.

Robinson, K. (2015). Creative Schools: The Grassroots Revolution That's Transforming Education. New York: Viking Press.

Sizer, T. R. (1984). Horace's Compromise: The Dilemma of the American High School. New York, NY: Houghton Mifflin.

Sizer, T. R. (1992). Horace's School: Redesigning the American High School. New York, NY: Houghton Mifflin.

Sizer, T. R. (1996). Horace's Hope: What Works for the American High School. New York, NY: Houghton Mifflin.

Sundararajan, A. (2015, July 25). The 'Gig' Economy is Coming: What Will it Mean For Work? The Guardian. http://www.theguardian.com/ commentisfree $/ 2015 /$ jul $/ 26 /$ will-we-get-by-gig-economy.

Thompson, D. (2015, July/August). A World Without Work. The Atlantic.

Tyack, D., \& Cuban, L. (1995). Tinkering Toward Utopia: A Century of Public School Reform. Cambridge, MA: Harvard University Press.

Winner, E., Goldstein, T., \& Vincent-Lancrin. S. (2013). Art for Art's Sake? The Impact of Arts Education, Educational Research and Innovation. Paris, France: OECD Publishing. http://www.oecd.org/education/ceri/ART\%20FOR\%20 ART\%E2\%80\%99S\%20SAKE\%20OVERVIEW_EN_R3.pdf. 
Open Access This chapter is licensed under the terms of the Creative Commons Attribution 4.0 International License (http://creativecommons.org/licenses/ by $/ 4.0 /$ ), which permits use, sharing, adaptation, distribution and reproduction in any medium or format, as long as you give appropriate credit to the original author(s) and the source, provide a link to the Creative Commons license and indicate if changes were made.

The images or other third party material in this chapter are included in the chapter's Creative Commons license, unless indicated otherwise in a credit line to the material. If material is not included in the chapter's Creative Commons license and your intended use is not permitted by statutory regulation or exceeds the permitted use, you will need to obtain permission directly from the copyright holder.

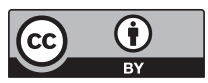

